\title{
Norwegian scabies in a resident of a nursing home misdiagnosed as dermatologic lesions of type 2 diabetes mellitus
}

\section{Przypadek świerzbu norweskiego u pensjonariusza domu opieki społecznej błędnie rozpoznany jako zmiany skórne towarzyszące cukrzycy typu 2}

Jacek Kasznicki, Marcin Kosmalski, Józef Drzewoski

Department of Internal Medicine, Diabetology and Clinical Pharmacology, Medical University of Lodz, Central Clinical Hospital USK WAM-CSW, Lodz, Poland

Przegl Dermatol 2014, 101, 487-489

DOI: 10.5 | |4/dr.20|4.4695|

KEY WORDS:

nursing home, Norwegian scabies, outbreak.

SŁOWA KLUCZOWE:

dom opieki społecznej, świerzb norweski, epidemia.
ADRES DO KORESPONDENCJI:

Jacek Kasznicki MD, PhD

Department of Internal Medicine, Diabetology and Clinical

Pharmacology Medical University of Lodz Central Clinical Hospital USK WAM-CSW

251 Pomorska St

92-213 Lodz, Poland

e-mail: jacek.kasznicki@ umed.lodz.pl

\section{ABSTRACT}

Introduction. Norwegian (crusted, hyperkeratotic) scabies is a relatively rare form of the disease, but it is highly contagious and easily transmitted. Although skin lesions are typical for that form of the disease, they differ substantially from those observed in typical infection with Sarcoptes scabiei.

Objective. To present the difficulties in the diagnosis of Norwegian scabies.

Case report. We describe a case of an elderly patient, a resident of a nursing home, with Norwegian scabies in whom itching and skin lesions were initially misdiagnosed as a dermatologic complication of type 2 diabetes mellitus. Additionally, in the nursing home, the results of the implemented therapy were not checked appropriately, which resulted in an outbreak of scabies in the institution as well as infection of several family members.

Conclusions. Considering the fact that pharmacological treatment of Norwegian scabies does not differ from other forms of this disease, it seems that early diagnosis and appropriate treatment planning are crucial to prevent transmission of the infection.

\section{STRESZCZENIE}

Wprowadzenie. Świerzb norweski jest stosunkowo rzadką odmianą tej choroby, ale najbardziej zakaźną. Zmiany skórne, jakkolwiek charakterystyczne dla tej postaci schorzenia, nie przypominają zmian obserwowanych w przebiegu typowej infekcji Sarcoptes scabiei.

Cel pracy. Przedstawienie trudności diagnostycznych w przypadku świerzbu norweskiego.

Opis przypadku. W pracy przedstawiono przypadek świerzbu norweskiego u rezydenta domu opieki społecznej, który początkowo błędnie zdiagnozowano i leczono jako zmiany skórne towarzyszące cukrzycy typu 2. Dodatkowo wyników leczenia nie skontrolowano, co spowodowało rozprzestrzenienie infekcji wśród innych pensjonariuszy tego ośrodka i niektórych członków rodziny osoby zakażonej.

Wnioski. Ze względu na fakt, że leczenie świerzbu norweskiego jest typowe, niezwykle istotna jest znajomość obrazu klinicznego oraz za- 
planowanie procesu terapeutycznego. Przedłużenie procesu diagnostycznego nie tylko opóźnia zastosowanie odpowiedniego leczenia, lecz także może sprzyjać szybkiemu rozprzestrzenianiu się choroby.

\section{INTRODUCTION}

Norwegian (crusted, hyperkeratotic) scabies is a relatively rare form of the disease, but unfortunately it is highly contagious and easily transmitted. Although skin lesions are typical for that form of the disease, they differ substantially from those observed in a common typical infection with Sarcoptes scabiei. That is why, especially in the early phase of the disease, it is relatively often misdiagnosed and should be differentiated from other dermatological lesions (Table 1). Prolongation of the diagnostic process not only delays implementation of the appropriate treatment, but also may facilitate transmission of the infestation. This is especially dangerous in institutions such as nursing homes, hospitals, boarding schools, prisons, camps and other similar facilities. In inpatient settings it may be responsible for outbreaks of scabies both among residents as well as medical personnel.

\section{OBJECTIVE}

We describe an elderly patient, a resident of a nursing home, with Norwegian scabies in whom itching and skin lesions were initially misdiagnosed as dermatologic complication of type 2 diabetes mel-

Table I. Differential diagnosis of Norwegian scabies

Tabela I. Diagnostyka różnicowa świerzbu norweskiego

\begin{tabular}{l}
\hline Acute urticaria \\
\hline Allergies \\
\hline Dermatitis (atopic, contact, herpetiformis) \\
\hline Eczema \\
\hline Folliculitis \\
\hline Insect bites \\
\hline Lupus \\
\hline Pityriasis \\
\hline Skin infections (fungal, bacterial) \\
\hline Syphilis \\
\hline Vasculitis
\end{tabular}

litus. Additionally, the results of the implemented therapy were not checked appropriately, which resulted in an outbreak of scabies in the institution as well as infection of several family members. Considering the fact that pharmacological treatment does not differ from other forms of scabies, it seems that early diagnosis and appropriate treatment planning are of key importance.

\section{CASE REPORT}

A 75-year-old woman was admitted to our department from a nursing home in March 2013 due to severe hypoglycemia associated with erroneous insulin injection. On examination the patient was confused, and presented with tachypnea, an elevated pulse rate $(110 / \mathrm{min})$ and high blood pressure (200/100 mm Hg). Additionally, the patient had had a widespread, red, itchy, scaly rash for several weeks and hyperkeratotic crusted lesions on both hands and feet (Figure 1). The blood glucose level was 1.65 $\mathrm{mmol} / \mathrm{l}$, and urea, creatinine, electrolyte, glycated hemoglobin $\left(\mathrm{HbA}_{1 \mathrm{c}}\right)$, lipid profile, thyroid function and liver enzyme activities were within the normal range. The patient had a moderately elevated total white blood cell count with mild peripheral eosinophilia.

Several years ago the patient was diagnosed with type 2 diabetes mellitus, hypertension and mild cognitive impairment. Since then she has been treated with human premixed insulin bid, ramipril, bisoprolol and aspirin in a low dose. At the beginning of February 2013, skin lesions diagnosed as a dermatological complication of diabetes appeared, and her general practitioner prescribed topical corticosteroids and oral antihistamine. The signs and symptoms persisted despite treatment. It is worth mentioning that in the nursing home the effect of the prescribed medications was not checked for the following several weeks.

The family members visiting the patient in the hospital also complained of similar skin signs and symptoms, especially in the interdigital spaces. Moreover, it was proved that other residents of the nursing home had similar skin lesions and complained of severe itching. Based on the clinical picture, scabies was suspected. The ink test was neg- 


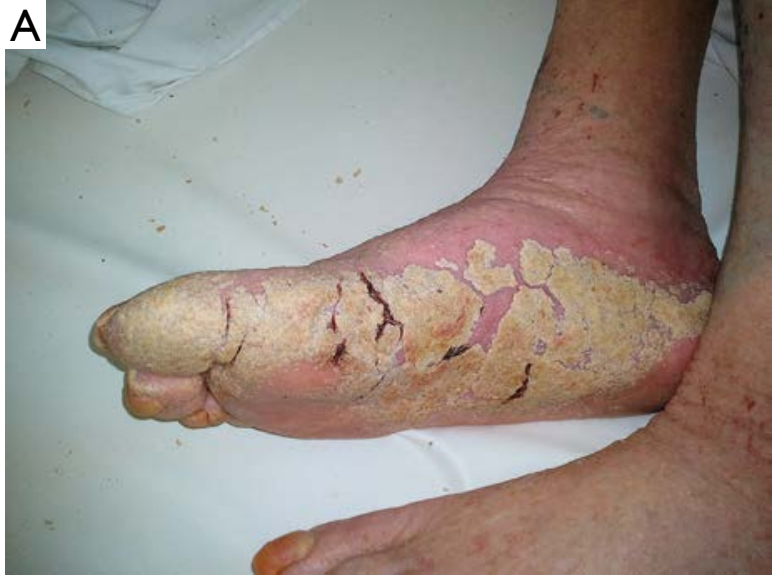

Figure I. Crusted scabies in a resident of a nursing home

Rycina I. Zmiany skórne u pensjonariuszki domu opieki społecznej

ative, but multiple superficial skin scrapings taken from the skin lesions showed plentiful adult mites, eggs and fecal pallets of Sarcoptes scabiei. Histopathological examination of the skin lesions was not performed.

The personnel of the nursing home and family members of nursing home residents were immediately informed about our diagnosis. The patient was treated with crotamiton, and no other pharmacological treatment was introduced. The itching quickly disappeared and the rash was resolving gradually.

\section{DISCUSSION AND CONCLUSIONS}

Norwegian scabies is a severe, rare form of scabies, most often seen in residents of nursing homes, immunocompromised, malnourished and elderly patients [1]. The suspicion of scabies usually arises from the medical history and examination of the patient. However, the definitive diagnosis is made upon the identification of mites, eggs, eggshell fragments, or mite pellets in skin samples. That is why, whenever possible, the diagnosis of scabies should be confirmed by identifying the mite or mite eggs [2]. Misdiagnosis of scabies has two serious conse-

Received: 22 V 2014

Accepted: 21 X 2014

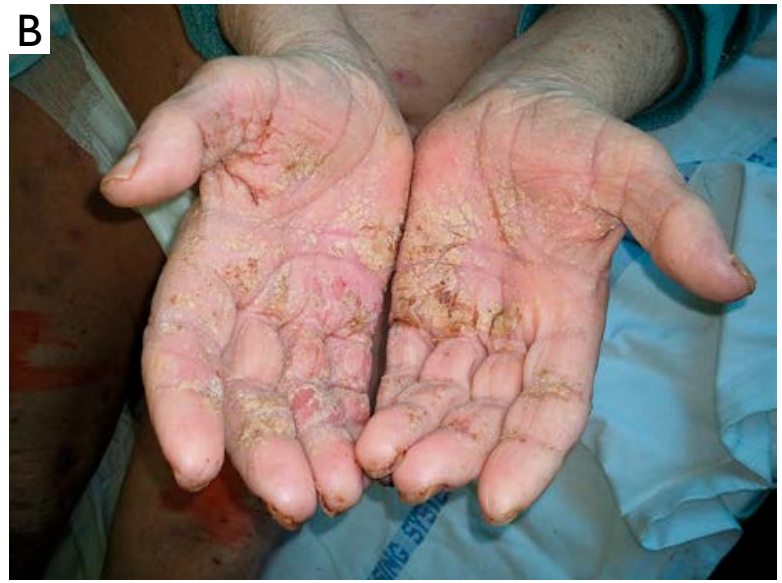

quences. Firstly, as the number of mites may exceed a million, Norwegian scabies may trigger an epidemic [3]. Secondly, the skin eruptions may become infected, most often with Staphylococcus aureus, which sometimes leads to sepsis [4]. Therefore, residents of nursing homes, elderly and immunocompromised people with either skin lesions or symptoms should be screened for scabies. If the disease is confirmed, the infection should be managed according to local Guidelines for Outbreaks of Scabies in long-term facilities. Additionally, the effect of prescribed therapy must be monitored.

\section{References}

1. Hopper A.H., Salisbury J., Jegadeva A.N., Scott B., Bennett G.C.: Epidemic Norwegian scabies in a geriatric unit. Age Ageing 1990, 19, 125-127.

2. Scabies fact sheet. Atlanta: Centers for Disease Control and Prevention (accessed March 24, 2014; at http://www.cdc. gov/ncidod/dpd/parasites/scabies/factsht_scabies.htm)

3. Roberts L.J., Huffam S.E., Walton S.F., Currie B.J.: Crusted scabies: clinical and immunological findings in seventy-eight patients and review in the literature. J Infect 2005, 50, 375-381.

4. Almond D.S., Green C.J., Geurin D.M., Evans S.: Lesson of the week Norwegian scabies misdiagnosed as an adverse drug reaction. BMJ 2000, 320, 35-36. 